\title{
African American Males Learning Online: Promoting Academic Achievement in Higher Education
}

\author{
Susan G. Salvo, Kaye Shelton, and Brett Welch \\ Lamar University
}

\begin{abstract}
Online education is expanding within higher education. However, attrition rates for African American males enrolled in higher education in general, and in online courses specifically, is on the rise. Because the future of our nation depends on how well our educational institutions develop, nurture, and deploy talent, this study identified factors that promoted online course completion among African American male undergraduate students. The researchers interviewed 10 males who successfully completed online courses and identified significant themes. Factors that contributed to online course completion were financial assistance, prior academic achievement, previous information technology (IT) training, continuous academic enrollment, student selection of topics perceived as uncomplicated and less demanding or familiar due to sufficient prior knowledge, use of handheld digital devices, and a non-prejudicial learning environment. This study also revealed challenges and obstacles encountered by participants. Based on these findings, the researchers made recommendations that include strategies policymakers and educationalists can implement to promote academic achievement and degree attainment among African American males in higher education.
\end{abstract}

Keywords: distance learning, online education, African American students, male students, best practices, academic achievement

Salvo, S.G., Shelton, K., \& Welch, B. (2019). African American males learning online:

Promoting academic achievement in higher education. Online Learning, 23(1), 22-36. doi:10.24059/olj.v23i1.1390

\section{African American Males Learning Online: Promoting Academic Achievement in Higher Education}

Post-secondary education has become more accessible to a wider range of students since the arrival of online education (Allen, Seaman, Poulin, \& Straut, 2016; McCoy, 2012), and substantial use of online courses within education is predicted in the future (Allen \& Seaman, 2014). However, evidence suggests proliferation of online education may hinder the ability of some populations to attain a post-secondary academic degree. Researchers identified at-risk populations to include low-income students (Jaggars \& Bailey, 2010), academically underprepared students (Figlio, Rush, \& Yin, 2013; Jaggars \& Bailey, 2010), students with lower prior grade point averages (Cochran, Campbell, Baker, \& Leeds, 2013; Figlio et al., 2013; Xu \& Jaggars, 2014), male students (Figlio et al., 2013; Xu \& Jaggars, 2014), and African American students (Xu 
\& Jaggars, 2014). Indeed, African American males are particularly at risk for online learning attrition in higher education due to lack of academic preparation (Institute for Higher Educational Policy, 2010; National Center for Education Statistics, 2016). African American males have been recognized as an endangered species in higher education (Gilkey, 2012; Jackson, 2014; Washington, 2013). In fact, Dyce (2013) declared lack of participation among African American males as the most important issue facing American higher education today.

According to the National Center for Education Statistics (2015), completion rates for a bachelor's degree among African American males is a dismal 17\%, which is the second lowest reported educational outcome in the United States within population subgroups (Hispanic males received the lowest score of $13 \%$ ). In addition, a demographic shift is taking place, with African American, Hispanic, and Asian populations expected to increase to approximately half of the total U.S. population by 2050 (Ortman \& Guarneri, 2009). With upcoming changes in demographics, combined with growth in online education and attrition among African American males, it is important to ensure African American males are successful in their online courses and have the ability to fulfill degree requirements (Palmer, Davis, Moore, \& Hilton, 2010).

The objective of this article is to share findings of a 2017 investigation into factors that may have contributed to online course completion among African American male undergraduate students. By identifying the backgrounds, competencies, and experiences of successful African American online learners, administrators and educationalists can better predict online course success and circumvent failures by allocating appropriate resources at the proper times. This approach improves online course completion rates and ultimately graduation rates for all African American males so they can enjoy the benefits of higher education (Bambara, Harbour, Davies, \& Athey, 2009; Palmer et al., 2010).

\section{Review of Related Literature}

The U.S. Department of Education (National Center for Education Statistics, 2011) reported African Americans are more likely than any other demographic group to enroll and complete their entire academic undergraduate coursework online (Moore, 2014). Ironically, historically Black colleges and universities (HBCUs) have been slow to create online programs for their students, with only $18 \%$ of 105 HBCUs offering online degrees. A primary reason for this decision were results from a longitudinal study that found on-campus engagement enhances retention (Astin, 1993). Due to high attrition rates for African American college students, HBCUs tend to focus their attention on face-to-face course offerings and programs (Flowers, White, Raynor, \& Bhattacharya, 2012). However, some studies found African American students were significantly less likely to enroll in online courses compared with White students (Flowers et al., 2012; Shea \& Bidjerano, 2014). However, African American students and students attending HBCUs who enrolled in online courses did so for the same reasons as other students who did not attend HBCUs — convenience (Kwun, Alijani, Mancuso, \& Fulk, 2012; Moore, 2014).

African American online students tend to have lower grades compared with their White peers, which suggests that achievement gaps found in many traditional educational programs also exist in online programs (Rovai \& Ponton, 2005). Reasons why these gaps exist are unknown. However, Rovai and Ponton (2005) offered clues, including reduced opportunity to hear the professor's explanations and examples and a lack of nonverbal student cues that may indicate students are confused or not grasping the material. African American online students also experienced lower perceived learning gains (Flowers, Flowers, Flowers, \& Moore, 2014; Rovai \& Ponton, 2005), fewer posting behaviors (Rovai \& Ponton, 2005), less sense of a learning 
community (Rovai \& Ponton, 2005), and lower satisfaction scores (Ke \& Kwak, 2013). Ashong and Commander (2012) found both African American and White students had positive views of online learning, but African American students reported significantly less positive views regarding the online feature of asynchronicity. It appears many African American students have a much stronger preference for real-time learning (Ashong \& Commander, 2012) and face-to-face interactions (Merrills, 2010; Rovai \& Gallien, 2005) characteristic of traditional campus-based courses.

African American students reported fewer microaggressions in online classrooms (Hall, 2010), which indicates online delivery may create a culturally neutral environment for these students (Stanley, 2014), allowing some students to distance themselves from negative stereotypes (Collins, 2014), especially students with past negative experiences in educational settings (Romero \& Usart, 2014). Some African American students who withdrew from online courses indicated their decisions were partly due to inadequate technology and computer skills; insufficient levels of technical support; and perceived course difficulty, including problems accessing online course materials and online tools (Moore, 2014). African American online learners include older students (Collins, 2014; Williams, 2015), female students (Williams, 2015), full-time students (Williams, 2015), and students who either worked full-time or were unemployed (Williams, 2015). African American online learners had higher incomes (Collins, 2014), were independent (Collins, 2014) and unmarried with dependents (Williams, 2015), had a strong sense of positive racial identity (Collins, 2014), and had a high degree of cultural awareness (Rovai \& Gallien, 2005).

There are few investigations of African American males learning online, with two involving high school students (Corey \& Bower, 2005; McCoy, 2012), one exploring undergraduate students (Moore, 2014), and one examining male college students of color with the majority being Hispanic, not African American (Tucker, 2014). McCoy (2012) conducted a phenomenological study of six African American male high school students and noted they enjoyed the flexibility and independence of learning online and experienced increased self-esteem and reduced racial prejudice (McCoy, 2012). Participants reported online instructors were responsive in regard to electronic communication and prompt in grading of assignments, which increased their enjoyment of learning online. Furthermore, participants indicated online learning helped prepare them for college and future careers. However, participants struggled with technology and indicated a preference for African American online instructors. These factors had a negative impact on their learning experiences and their attitudes related to the future of online education for African Americans (McCoy, 2012). Moore (2014) also used a phenomenological approach during an investigation into reasons why African Americans withdrew from their undergraduate online programs. Fifty percent of participants in this study were male. Lack of interaction and inefficient communication were reasons why the majority of males in Moore's study left their online programs. These participants expressed a need for verbal communication, a desire for face-time, problems communicating with faculty and staff via electronic media, discomforts with technology, and insufficient technology support from the education institution.

Corey and Bower (2005) conducted a case study of an African American male high school student enrolled in an online math course at the school's media center, in addition to a face-to-face math course taught by a White female teacher. The student was identified as an educationally "at risk" student with a history of below-average grades in mathematics. The student claimed a language barrier existed in the face-to-face math course due to the terminology used by the teacher and that he did not experience this barrier in the online course. With the addition of online learning, the student achieved improved scores. The student noted fewer social norms in the online course, which promoted peer-to-peer interactions via an electronic message board, compared with the 
traditional classroom. The study findings suggested the online course was effective at reducing cultural and learning barriers and had positive academic implications for the participant (Corey \& Bower, 2005).

Tucker (2014) identified conditions within and beyond online environments that impacted academic success among male college students of color at a predominantly White college, while exploring race and racism and how these may affect academic progress. Tucker (2014) used a case study design that included data collection methods of web-based surveys, phone interviews, and a single, two-person group interview. Online course completion was not required for participation. Tucker (2014) identified factors within online learning environments that supported academic success, which included convenience and flexibility, a color-blind environment, support from and immediate interactions with faculty, and institutional support. Factors beyond the online learning environment were student characteristics of academic self-efficacy and educational resilience. In addition, students of color preferred traditional offline social supports from close social ties, which may serve to reduce the feelings of isolation and alienation commonly experienced by these students when learning online (Tucker, 2014). Limitations of this investigation were that approximately $20 \%$ of survey respondents were African American males, and therefore were an underrepresented population (e.g., 10 African Americans; five American Indians/Alaskan Indians; three Asian Americans/Pacific Islanders; 30 Hispanic Americans/Latinos). Of the nine phone interviews, only one African American was interviewed. While these studies add to the body of knowledge, clearly there is a gap in the research that investigates why some African American male university students completed online courses.

A deeper understanding is needed of the backgrounds, competencies, and strategies used by successful African American male online learners to identify factors that may influence online course completion and academic achievement (Merrills, 2010). Results of this study could help educationalists create or strengthen programs that promote online course persistence and improve college graduation rates for African American males. Study results may also provide an impetus and direction for expanding online programs among underserved populations in ways that promote academic achievement and degree attainment, as well as fill in a gap in the literature in the field of online education.

\section{Methods}

This qualitative research study employed a phenomenological approach to investigate factors that contributed to successful completion of online courses for 10 African American male undergraduate students. This section discusses the methodology used to conduct the investigation and includes information about the participants, the setting, data collection, and treatment of the data.

The participants in this study were enrolled at an accredited public university in the southern region of the United States. The university had a 2016 fall enrollment of 7625 students; 6961 of the total enrollment were classified as undergraduates. Forty percent of the undergraduate student population were male. Sixteen percent of the undergraduate student population were African American.

The participants were selected using a purposive sampling method, which allowed investigators to choose individuals who could best inform an understanding of a central phenomenon and who could best answer the research questions, which included inquiries regarding economic factors, technologic experiences, and academic factors, as well as challenges 
and obstacles they encountered. Participants were African American male undergraduate students who had successfully completed an online college course indicated by a passing grade. The decision to use only those students who had passed an online course was intentional. The researchers were aware that eliminating those students who did not successfully complete an online course would limit the opportunity to compare the two groups. However, the researchers decided to narrow the focus on revealing the characteristics of those who have had success in online learning. To this end, the researchers gave more attention to the ways these individuals successfully completed online course work. Participant information is located in Table 1.

Table 1.

Participant Demographics

$\begin{array}{cllll}\text { Participant no. } & \text { Age } & \text { Academic concentration } & \text { Enrollment status } & \text { GPA } \\ \text { P1 } & 19 & \text { Biology } & \text { Junior } & 3.6 \\ \text { P2 } & 28 & \text { Criminal Justice } & \text { Junior } & 3.0 \\ \text { P3 } & 21 & \text { Finance } & \text { Junior } & 3.5 \\ \text { P4 } & 21 & \text { Psychology } & \text { Senior } & 3.3 \\ \text { P5 } & 22 & \text { Accounting } & \text { Senior } & 2.6 \\ \text { P6 } & 28 & \text { General Studies } & \text { Senior } & 3.1 \\ \text { P7 } & 35 & \text { Nursing } & \text { Senior } & 3.3 \\ \text { P8 } & 20 & \text { Nursing } & \text { Junior } & 3.2 \\ \text { P9 } & 26 & \text { General Studies } & \text { Senior } & 2.1 \\ \text { P10 } & 20 & \text { Business } & \text { Junior } & 2.5\end{array}$

After permission was obtained from the Institutional Review Board, participants were recruited. Recruitment consisted of purposeful snowball sampling. Semi-structured interviews were conducted and recorded. A semi-structured design allowed participants to talk at length about their academic achievement strategies in order to give the investigators a deeper sense of the participants themselves and of their distance learning experiences.

Data from recorded interviews were transcribed. Each participant was sent his transcript for review. Each participant was asked to approve his transcript before the investigators used it for data analysis. Once the transcripts were returned, 10 separate spreadsheets were created and examined for emerging themes. Next, the data were coded. A list of emergent codes was created using a constant comparative method.

Interview recordings and transcripts were stored on a passcode-protected computer in an office. Informed consent documents were stored at a different secure location. Backup copies of files were stored on a secure, cloud-based file storage network.

\section{Results}

The purpose of this investigation was to identify factors associated with online course completion among African American male undergraduate students. In the role of phenomenologists, the researchers assumed human experiences could be expressed and made visible in the way participants experienced the phenomenon (Dukes, 1984). Ten participants were interviewed to answer the research questions. Significant statements were identified, thematized, and aligned with the research questions. 
All ten participants utilized scholarships, grants, or student loans to pay for their education, which led researchers to believe that financial assistance had a positive impact on educational outcomes for African American male university students taking online courses. Technologic factors that had a positive impact on online course completion included previous information technology (IT) courses such as keyboarding, software applications, and computer literature, as all participants had taken IT courses during high school. In addition, 80\% of participants used handheld digital devices such as smartphones to complete online course-related tasks because it was "easier" and the "the fastest way to do it," and "usually the one I do most of my work on." Computers were used "to type something, like a long thesis paper." It is unknown if financial assistance, IT courses taken during high school, or use of handheld digital devices for educational purposes are also characteristics among unsuccessful African American male undergraduate students taking online classes.

The majority of African American male undergraduate students who completed online courses in this investigation had experienced prior academic achievement (90\%). One participant stated, "I was enrolled in college while attending high school and transferred 46 hours into my degree plan. I started college as a junior." Another participant revealed similar experiences prior to beginning college, "While still in high school, I was taking college courses. I would actually take classes on the college campus for half the day." Yet another participant indicated he "took a few advanced placement courses in high school" and completed "Math 113 my senior year" and "was able to get college credit for the math class." In addition, all participants indicated they were continuously enrolled in educational institutions and attended a university upon high school graduation, with some participants dually enrolled, as mentioned previously.

Seventy percent of participants selected online courses in subjects they perceived as easy or uncomplicated or in subjects with which they were familiar due to sufficient prior knowledge. One participant stated, “The online classes I take aren't necessarily rigorous classes. I take subjects that are not difficult for me to understand." Another participant reiterated this sentiment and expounded on the theme, saying that a face-to-face class helped him succeed in an online class by this statement:

You teach yourself the subject in online classes, so unless you're very smart or you kinda know what the subject is, don't take it online. I dropped Accounting in class because it was really hard, so I tried it online, and I did better on the online. I passed the online course because I had the background knowledge of what I learned in class. So even though I failed the first time, I still gained something and applied it to the online class.

The theme of prior knowledge supporting distance learning was reiterated by another participant:

I took a psychology class face-to-face and later took a psychology class online. The online psychology required the foundation of the face-to-face class, and the knowledge I had from the face-to-face class was brought over because I took it afterwards. So I had a better grasp. This order seemed more beneficial to me.

Math was singled out by several participants as a topic not to take in an online format with comments such as

If I'm weak in a subject, I need to take it face-to-face. Math and stuff, I need to be sitting in the classroom looking at the teacher's face because I don't know how to do it. Some people can read stuff, go from that. If it's hard, I need to hear it explained to me, then I be straight. But no, if it's some writing or research, I could look at that and 
do that, but if it's something that I need to break down, like math, no, I need to see the teacher's face.

And

Some classes I need to take face-to-face. Mostly like math class and maybe chemistry. Yeah, I need to take these face-to-face; I don't want to do it online. I think online will be harder for me. I need to see them face-to-face and talk with the teacher. You know, in person and stuff like that. It is kind of a strategy

In another finding, $40 \%$ of participants indicated they felt online learning created a nonprejudicial learning environment. When asked about differences between face-to-face and online courses, one participant stated,

It's an open forum where everyone has the opportunity to say what they want to say. In the classroom you may not get picked. That's being honest. In online classes, everyone has the same access. I hate to talk about all that kinda stuff. You know, race and that. But I see fewer people of color raising their hands. Because they already know that it's not going to happen. Now we can decide. In online classes, it takes all of those variables away. It makes you feel comfortable. No anxiety about any of that. I really do like it.

Another admitted,

I dropped History 101. I was on my phone in class. The teacher saw me doing it and kicked me out of class. The guy next to me was doing the same thing, but wasn't African American, and he got to sit in class. Now I use the Internet and check the teacher. See who they are and to see if they know athletes. If they are athlete friendly, I'm more apt to take the class face-to-face. If I don't want to be involved with a teacher, I take it online.

Some participants preferred online courses because they were less competitive, indicated by statements such as

I am not good speaking in front of people. The online format works for me because there's less competition and less pressure, and it's not time-limited, so I can sit back and think before saying why I feel a certain way about a topic...

And

In an online class, I go on my own pace. There's no pressure to worry about who's finishing first. When you take a test in class, people look around, see who's finished first. When I'm online I can go at my own pace. I don't have to worry about who's done and who's not done. There's less competition.

This investigation also examined challenges and obstacles encountered by African American male undergraduate students who completed online courses. Participants revealed challenges such as lack of professor interaction, lack of immediate feedback, insufficient number of examples, lack of notifications, lack of teacher-directed instruction, and lack of teachermediated assessments.

For example, one participant said, "Sometimes the material can get pretty hard, and you need a lot of examples. Typically in online classes you don't get too many examples. So I would like feedback and more examples." Another participant found online courses challenging due to lack of examples, including explanations of course outlines: "Some online courses are hard to follow because the teacher doesn't necessarily inform us what we are supposed to do. They just 
make out a quick outline without explaining what we need to do. It's confusing." These thoughts were echoed by other participants in remarks such as the need for

...more interaction with our professor. He was slow getting back to our grades and everything. Be quick to feedback. I mean, I know we're all busy, but feedback needs to be in a timely fashion. A timely manner. And grade-wise, just be pretty punctual at that

and "I would suggest a whole lot more feedback." When comparing face-to-face with online learning, one participant discussed the importance of immediate responses and liked to "ask questions to the teacher right there physically." He also did not like emailing the professor because "emailing doesn't really work. Sometimes it takes them about two or three days to reply. But in class you can ask right then and there and don't have to wait or nothing." When asked how to improve online education, one participant suggested, "...more video lecturing. Even maybe live lecturing. Just some lecturing where you could talk back. To where you can visually see them, and they can explain it to you. Just more live lecturing."

Remembering coursework and tests was one participant's biggest challenge. He confessed "I was just moving so fast. I was doing so much, playing basketball, working, doing so much" and that he "didn't have a computer, except for when I was at school. I didn't live on campus." He also admitted that "When I first started taking online classes, my grades weren't very good, because I would forget. I still forget about assignments and tests. That's my biggest thing with online classes. Yes, I just forget." When asked why he forgot, he replied,

I'm doing so much other stuff. If I don't see it, like, if it isn't in my hand or I don't hear somebody say it, I'm not going to remember it, and that was going on with my online class.

He also said he recently missed a test because

I totally forgot about the online class, because I don't sit in front of a computer until I think about it. I'm trying to do this and do that and work, so I just forget. I would just forget, and I still forget now.

Another participant made a similar comment about notifications, but he was distinct in how he wanted to receive them with a preference for hearing and attested, "I like face-to-face over online. Online takes a lot of dedication, because you don't have to go to class, and there are deadlines. Online makes it easy to get behind on your assignments."

Another participant stated that assessments in face-to-face classes provided him opportunities to explain answers to the professor and receive immediate feedback, which helped him earn grades better than those in his online courses. He stated

For test situations, I prefer face-to-face tests, because if you give the short answer and your professor is there, you have leeway. They can understand what you are trying to say and give you feedback and partial credit while you are taking the test.

Another participant also preferred taking tests face-to-face, which he associated with better grades, as he illustrated:

In face-to-face, your teacher may give you credit for at least trying on a problem versus online, you might not. It depends on the teacher; if they go in and see what you're doing. In face-to-face classes, you can ask the teacher during the test. Of course, they don't tell you the answer, but you can tell them, like, 'What does this mean? Am I on the right track?' 
This same participant experienced obstacles with computer-mediated assessments, such as program input restrictions, when he claimed, "I am a better student in face-to-face classes" because online course assessments are "graded by a computer," and computer grading is "very accurate and don't give you points for trying something." He also noted that once he "did an assignment online and the computer marked it wrong" because it was "very particular on what you type in. If you type a little space, it's going to be wrong." He insisted he "typed it in how the computer wanted it, but it still said it was wrong, and this decreased my grade."

\section{Discussion}

In summary, after conducting a qualitative phenomenological study examining economic, academic, and technologic influences, as well as challenges, encountered by 10 African American male undergraduate students who successfully completed online courses, the following factors were found: financial assistance, prior academic achievement, previous training in information technology during high school, continuous academic enrollment, online courses on topics perceived as uncomplicated and less demanding or on topics that were familiar to the students due to sufficient prior knowledge, use of handheld digital devices, and a non-prejudicial learning environment. Challenges and obstacles encountered by many participants included lack of professor interaction, lack of immediate feedback, insufficient number of examples, lack of notifications, lack of teacher-directed instruction, and lack of teacher-mediated assessments.

Financial assistance also improved educational outcomes for African American male college students in face-to-face courses (Robertson \& Mason, 2008) and among low-income online learners (Jaggars \& Bailey, 2010). This finding suggests that access to financial resources to cover education-related expenses may support online course completion and academic degree attainment. Cochran et al. (2013) also found students with high previous academic achievement are more likely to persist in online courses. Varela, Cater, and Michel (2012) noted achievement orientation is a significant predictor of online learning success. Furthermore, McDaniel, DiPrete, Buchmann, and Shwed (2011) discovered educational attainment among African American males is more likely when there is no delay between high school graduation and college enrollment. Xu and Jaggars (2013) found certain academic subject areas appear more difficult to learn in the online context, and some subjects may require intensive student-instructor interaction. Bambara et al. (2009) noted online students struggled learning unfamiliar and complex course materials and Jaggars (2014) observed that college students preferred taking easy academic subjects online and difficult or important subjects face-to-face. Based on the results of this study and findings from other studies, supporting academic achievement, enrollment in information technology courses, facilitating higher education enrollment immediately after high school graduation, and ample online academic support for students learning difficult subjects may promote online course completion among African American male undergraduate students.

Several technologic factors were common among participants, including information technology courses taken during high school and use of handheld digital devices such as smartphones. This study supports Newell's (2007) and Fairlie's (2012) research, which revealed computer literacy and skills were important requisites for online course success. In addition, Zickuhr and Smith (2012) noted African Americans are likely to use their smartphones as the primary source of Internet access. While other studies linking online learning success with use of handheld digital devices have not been presented, educational institutions might consider using online course materials that are compatible with smartphones and ensuring that activities and tasks required for online courses can be completed on various smartphone operating systems. 
Several successful online learners indicated a preference for online courses because they did not feel judged by the color of their skin or the speed of their responses during discussions or in testing situations. This finding contributes to previous findings that distance learning is valuable to African Americans who "could benefit more from online courses where they can be more uninhibited in online interactions," as noted by Romero and Usart (2014). This investigation also supports Hall (2010), who found African American students experienced "fewer microaggressions in the online environments," and Collins (2014), who discovered students used online classrooms to distance themselves from the stereotypes about being African American. To facilitate a culturally neutral learning environment, educationalists might consider expanding online discussion topics to reflect ideas and events from different points of view. For example, perspectives of people of different racial and ethnic backgrounds, people who practice different religions and faiths, or people of different nationalities or who live in different countries should be included in discussions either by instructional design or by the voices of diverse students within the online learning environment. In addition, rather than learn about events from the mainstream or the victor's point of view, current and historical events should also be examined from the perspective of the oppressed or overpowered.

This study also inquired about challenges and obstacles African American male undergraduate students who completed online courses encountered. Many of the participants stated they experienced lack of professor interaction, lack of immediate feedback, insufficient number of examples, lack of notifications, lack of teacher-directed instruction, and lack of teacher-mediated assessments, which led the researchers to speculate that these barriers may be related to a need for immediacy, clarity, and familiarity. The need for immediacy may be related to some participants' desire for quick responses to questions, quick evaluations on assessments, and timely notifications of upcoming events and deadlines. The conclusion about the importance of immediacy supports Tucker's (2014) research that found immediate interactions, including those from faculty, supported academic success among African American male college students. Tonsing-Meyer (2013) also found lack of immediate one-on-one communication and having to wait to have questions answered were a source of frustration among online learners.

With regard to clarity, some participants expressed a need to confirm that they understood directions they were expected to follow to complete assignments, projects, or assessments such as exams. This idea supports Horspool and Lange's (2012) conclusion that online students ask more questions than their face-to-face counterparts because online students need clarification. Fayer (2014) also found content clarification supported confidence and excitement and helped avoid learner confusion. Recommendations to address immediacy and clarity include providing ondemand academic support. This support may manifest in several ways. For example, if students desire face-to-face meetings with instructors or peer mentors, educational institutions might provide a drop-in space so students who need academic support including clarifying assignments can meet with appropriate individuals. Educational institutions might consider increasing the ease of contact between online students and academic support systems by utilizing multiple methods by which students can access immediate assistance. Methods may include email, phone, text, or making an appointment with an instructor at a time that is convenient for the student. A key element of this recommendation is brief response times by the institution, which may involve call centers that serve as intermediaries between students and the appropriate resource and ensures, perhaps by a follow-up message, that the students' academic needs were met in a timely manner. These types of accommodations may provide students ample academic support and adequately address many of the challenges encountered by students while completing online courses. 
In matters of familiarity, some participants expressed a need for familiar teacher-directed instruction that mimicked face-to-face classrooms when learning complex subjects. This study supports the findings of $\mathrm{Xu}$ and Jaggars (2013), who suggested certain subjects may require intensive student-instructor interactions. Ashong and Commander (2012) also found African American students have a stronger preference for real-time learning and reported significantly less positive views regarding the online feature of asynchronicity. To address this obstacle, institutions might consider providing multimodal instruction beyond the current text-based and video-based instructional methods for online courses. For multimodal instruction to be accomplished, educational institutions might consider becoming involved with the development and distribution of virtual reality and other cutting-edge technologies that can be accessed by online students when learning difficult concepts or procedures.

Limitations in this study were that findings were based on subjective stories of participants, and these findings may not be applicable to academically unsuccessful undergraduate African American males, academically successful or unsuccessful undergraduate African American females, students of any race or gender in other undergraduate programs, or students of any race or gender enrolled in grades K-12 or enrolled in master's or doctoral degree programs.

Findings of this study suggest several areas that merit further investigation. This study was limited to a mid-sized university in the South where African Americans represented less than 20\% of the population. Investigations conducted in larger universities, more racially diverse universities, or universities in other geographic regions would add to the knowledge base of African American male undergraduate students in distance learning environments. Participants indicated cultural neutrality of online learning environments was a factor in online course completion. While this perception was found in other studies (Collins, 2014; Hall, 2010; Romero \& Usart, 2014), it is likely subjective and deserving of more rigorous investigation. Quantitative methods would be very useful in informing this area of research.

Dyce (2013) said lack of participation among African American males is the most important issue facing American higher education today. Policymakers and educationalists must be committed to best practices in creating and delivering educational content that is equitable and accessible to a broader range of learners by removing economic, academic, technologic, and other barriers. Hughes (2010) recommended schools and educators assume all African American males need assistance and take anticipatory and aggressive actions to support these students rather than waiting for these students to contact them. Without a college degree, African American males are less likely to obtain gainful employment and are more likely to live in poverty or be incarcerated (Gibson, 2014). Steps must be taken to improve degree completion rates among African American males, which is only 17\% for a bachelor's degree (National Center for Education Statistics, 2015), especially with forecasted demographic changes (Ortman \& Guarneri, 2009), growth in online education, and high attrition rates among African American males (Palmer et al., 2010). By identifying the backgrounds, competencies, and experiences of successful African American male online learners, administrators and educationalists can better predict online course success and circumvent failures by allocating appropriate resources for these students. This approach improves online course completion rates and ultimately graduation rates for all African American males so they can enjoy the benefits of higher education (Bambara et al., 2009; Palmer et al., 2010). Certainly, the gentlemen interviewed in this study had a genuine interest in helping other students experience what they experienced: online learning success, advancement toward achievement in higher education, and fulfillment of personal and professional goals. 


\section{References}

Allen, I. E., \& Seaman, J. (2014). Grade change: Tracking online education in the United States. Babson Park, MA: Babson Survey Research Group and Quahog Research Group, LLC. Retrieved from http://www.onlinelearningsurvey.com/reports/gradechange.pdf

Allen, I. E., Seaman, J., Poulin, R., \& Straut, T. T. (2016). Online report card: Tracking online education in the United States. Babson Park, MA: Babson Survey Research Group and Quahog Research Group, LLC. Retrieved from http://onlinelearningsurvey.com/reports/onlinereportcard.pdf

Ashong, C. Y., \& Commander, N. E. (2012). Ethnicity, gender, and perceptions of online learning in higher education. MERLOT Journal of Online Learning and Teaching, 8(2), 98-110. Retrieved from http://jolt.merlot.org/vol8no2/ashong_0612.pdf

Astin, A. W. (1993). What matters in college: Four critical years revisited. San Francisco: Jossey-Bass.

Bambara, C. S., Harbour, C. P., Davies, T. G., \& Athey, S. (2009). Delicate engagement: The lived experience of community college students enrolled in high-risk online courses. Community College Review, 36(3), 219-238. doi:10.1177/0091552108327187

Cochran, J. D., Campbell, S. M., Baker, H. M., \& Leeds, E. M. (2013). The role of student characteristics in predicting retention in online courses. Research in Higher Education, 55(1), 27-48. doi:10.1007/s11162-013-9305-8

Collins, S. Y. (2014). Racial identity theory and its perceived impact for African American students in an online distance learning program (Doctoral dissertation). Available from ProQuest Dissertations and Theses database. (UMI No. 3682202)

Corey, D. L., \& Bower, B. L. (2005). The experiences of an African American male learning in the traditional and the online classroom-A case study. The Journal of Negro Education, 74(4), 321-331.

Dukes, S. (1984). Phenomenological methodology in the human sciences. Journal of Religion and Health, 23(3), 197-203.

Dyce, C. M. (2013). Disappearing into the unknown: The state of Black male achievement in American public schools. Multicultural Perspectives, 15(3), 165-167. http://dx.doi.org/10.1080/15210960.2013.809307

Fairlie, R. W. (2012). The effects of home access to technology on computer skills: Evidence from a field experiment. Information Economics and Policy, 24, 243-253. doi:10.1016/j.infoecopol.2012.06.001

Fayer, L. (2014). A multi-case study of student perceptions of online course design elements and success. International Journal for the Scholarship of Teaching and Learning, 8(1). https://doi.org/10.20429/ijsotl.2014.080113

Figlio, D. N., Rush, M., \& Yin, L. (2013). Is it live or is it internet? Experimental estimates of the effects of online instruction on student learning. Journal of Labor Economics, 31(4), 763-784. Retrieved from http://www.jstor.org/stable/10.1086/669930?seq=1\#page_scan_tab_contents 
Flowers, L. A., Flowers, L. O., Flowers, T. A., \& Moore, J. L. (2014). Examining the effects of online distance education of African American students' perceived learning. Black History Bulletin, 77(1), 21-26. Retrieved from http://v77n78.blackhistorybulletin.com/wpcontent/uploads/sites/8/2015/03/R8UR72304851U2211.pdf

Flowers, L. O., White, E. N., Raynor, J. E., \& Bhattacharya, S. (2012). African American students' participation in online distance education in STEM disciplines: Implications for HBCUs. Sage Open Journals, 2(2), 1-5. doi:10.1177/2158244012443544

Gibson, Y. B. (2014). The impact of mentoring programs for African American male community college students. Journal of Mason Graduate Research, 1(2), 70-82. Retrieved from http://journals.gmu.edu/jmgr/article/download/216/385

Gilkey, E. (2012). African American men and college: Understanding how they succeed (Doctoral dissertation). Available from ProQuest Dissertations and Theses database. (UMI No. 3512927)

Hall, J. (2010). African American doctoral students at for-profit colleges and universities: A critical race theory exploration (Doctoral dissertation). Retrieved from https://repository.lib.ncsu.edu/bitstream/handle/1840.16/6211/etd.pdf?sequence=1\&isAll owed $=\mathrm{y}$

Horspool, A., \& Lange, C. (2012). Applying the scholarship of teaching and learning: Student perceptions, behaviours and success online and face-to-face. Assessment \& Evaluation in Higher Education, 37(1), 73-88. http://dx.doi.org/10.1080/02602938.2010.496532

Hughes, R. L. (2010). Engaging African American males for education success. Gifted Child Today, 33(2), 55-61.

Institute for Higher Educational Policy. (2010). A snapshot of African Americans in higher education. Retrieved from http://files.eric.ed.gov/fulltext/ED521322.pdf

Jackson, J. (2014, January 20). The Black male: An endangered species? Neon Tommy: Annenberg Digital News. Retrieved from http://www.neontommy.com/news/2014/01/black-male-endangered-species

Jaggars, S.S. (2014). Choosing between online and face-to-face courses: community college student voices. American Journal of Distance Education, 28(1), 27-38.

Jaggars, S. S., \& Bailey, T. (2010). Effectiveness of fully online courses for college students: Response to a department of education meta-analysis. New York, NY: Community College Research Center, Columbia University.

Ke, F., \& Kwak, D. (2013). Online learning across ethnicity and age: A study of learning interaction participation, perception, and learning satisfaction. Computers \& Education, 61, 43-51. doi:10.1016/j.compedu.2012.09.003

Kwun, O., Alijani, G. S., Mancuso, L. C., \& Fulk, H. K. (2012). Student perceptions of online courses and behavior in historically Black colleges and universities (HBCU). Franklin Business \& Law Journal, 2012(2), 99-120.

McCoy, K. L. (2012). A study of African American males and their response to online learning (Doctoral dissertation). Available from ProQuest Dissertations and Theses database. (UMI No. 3546682) 
McDaniel, A., DiPrete, T. A., Buchmann, C., \& Shwed, U. (2011). The black gender gap in educational attainment: Historical trends and racial comparisons. Demography, 48(3), 889-914. doi:10.1007/s13524-011-0037-0

Merrills, J. M. S. (2010). Factors affecting nontraditional African American students' participation in online world literature classes (Doctoral dissertation). Available from ProQuest Dissertations and Theses database. (UMI No. 3434153)

Moore, D. (2014). An investigation of the attrition of African-American students in an online undergraduate program (Doctoral dissertation). Available from ProQuest Dissertations and Theses database. (UMI No. 3626928)

National Center for Education Statistics. (2011). The condition of education, 2011. (NCES 2011033), Indicator 43. Retrieved from https://nces.ed.gov/pubsearch/pubsinfo.asp?pubid=2011033

National Center for Education Statistics. (2015). The condition of education, 2015. Retrieved from http://nces.ed.gov/pubs2015/2015144.pdf

National Center for Education Statistics. (2016). Digest of education statistics, 2014. Retrieved from https://nces.ed.gov/pubs2016/2016006.pdf

Newell, C. C. (2007). Learner characteristics as predictors of online course completion among nontraditional technical college students (Doctoral dissertation). Retrieved from https://getd.libs.uga.edu/pdfs/newell_chandler_c_200705_edd.pdf

Ortman, J. M., \& Guarneri, C. E. (2009). United States population projection: 2000-2050. Retrieved from https://www.census.gov/population/projections/files/analyticaldocument09.pdf

Palmer, R. T., Davis, R. J., Moore, J. L., \& Hilton, A. A. (2010). A nation at risk: Increasing college participation and persistence among African American males to stimulate U.S. global competitiveness. Journal of African American Males in Education, 1(2), 105-124.

Robertson, R. V., \& Mason, D. (2008). What works? A qualitative examination of the factors related to the academic success of African American males at a predominantly White college in the South. Challenge: A Journal of Research on African American Men, 14(2), 67-89.

Romero, M., \& Usart, M. (2014). The temporal perspective in higher education learners: Comparisons between online and onsite learning. European Journal of Open, Distance and E-Learning, 17(1), 190-209. https://doi.org/10.2478/eurodl-2014-0013

Rovai, A. P., \& Gallien, L. B. (2005). Learning and sense of community: A comparative analysis of African American and Caucasian online graduate students. Journal of Negro Education, 74(1), 53-62.

Rovai, A. P., \& Ponton, M. K. (2005). An examination of sense of classroom community and learning among African American and Caucasian graduate students. Retrieved from http://olc.onlinelearningconsortium.org/sites/default/files/v9n3 rovai 1.pdf

Shea, P., \& Bidjerano, T. (2014). Does online learning impede degree completion? A national study of community college students. Computers \& Education, 75, 103-111. http://dx.doi.org/10.1016/j.compedu.2014.02.009 
Stanley, B. C. (2014). Online vs. face-to-face instruction: A comparison of engagement and gains for African-American and white students at predominantly white institutions (Doctoral dissertation). Available from ProQuest Dissertations and Theses database. (UMI No. 3625940)

Tonsing-Meyer, J. (2013). An examination of online instructional practices based on the learning styles of graduate education students. The Quarterly Review of Distance Education, 14(3), 141-149.

Tucker, W. G. (2014). Spaces for success in higher education: Males of color at an online predominantly white community college (Doctoral dissertation). Available from ProQuest Dissertations and Theses database. (UMI No. 3621155)

Varela, O. E., Cater, J. J., \& Michel, N. (2012). Online learning in management education: An empirical study of the role of personality traits. Journal of Computing in Higher Education, 24, 209. doi:10.1007/s12528-012-9059-x

Washington, M. (2013). Is the Black male college graduate becoming an endangered species? A multi-case analysis of the attrition of black males in higher education. LUX: A Journal of Transdisciplinary Writing and Research from Claremont Graduate University, 3(1), 119. doi:10.5642/lux.201303.20

Williams, K. (2015). The impact that technology and social systems have on African American student enrollment growth in totally online, hybrid/blended online, and face-to-face undergraduate degree programs (Doctoral dissertation). Available from ProQuest Dissertations and Theses database. (UMI No. 3707786)

Xu, D., \& Jaggars, S. S. (2013). Adaptability to online learning: Differences across types of students and academic subject areas. CCRC Working Paper No. 54. New York, NY: Community College Research Center, Columbia University. Retrieved from http://ccrc.tc.columbia.edu/media/k2/attachments/adaptability-to-online-learning.pdf

Xu, D., \& Jaggars, S. S. (2014). Performance gaps between online and face-to-face courses: Differences across types of students and academic subject areas. Journal of Higher Education, 85(5), 633-659. doi:10.1353/jhe.2014.0028

Zickuhr, K., \& Smith, A. (2012). Digital differences. Pew Research Center's Internet \& American Life Project, Washington, D.C., 1-41. Retrieved from http://pewinternet.org/Reports/2012/Digital-differences.aspx 